\title{
肺癌登録合同委員会報告 肺癌登録合同委員会による肺癌登録
}

○澤端 章好 ${ }^{1}$ 、奥村 明之進 ${ }^{1}$ 、淺村 尚生 ${ }^{2}$ 、中西 洋一 ${ }^{3}$ 、江口 研二 ${ }^{4}$ 、森 雅樹 ${ }^{5}$ 、野守 裕明 ${ }^{6}$ 、 藤井 義敬 ${ }^{7}$ 、宮岡 悦良 $^{8}$ 、横井 香平 ${ }^{9}$

${ }^{1}$ 大阪大学大学院医学系研究科 外科学講座 呼吸器外科、2国立がん研究センタ一中央病院 呼吸器外科、

${ }^{3}$ 九州大学大学院医学研究院 内科学講座 呼吸器内科、4 帝京大学医学部 内科学講座、

${ }^{5} \mathrm{JA}$ 北海道厚生連 札幌厚生病院 呼吸器科、6 慶應義塾大学医学部 呼吸器外科、

${ }^{7}$ 名古屋市立大学医学研究科 腫瘍·免疫外科、 ${ }^{8}$ 東京理科大学理学部 第二部数学科、

9 名古屋大学大学院医学系研究科 病態外科学講座 呼吸器外科学

当肺癌登録事業は, 日本肺癌学会, 日本呼吸器外科学会および日本呼吸器学会が設けた肺癌登録合同委員 会により行なわれ，登録症例の解析を行い，その結果を学術論文として発表するとともに，TNM 分類改訂 のための staging program に寄与している.

外科切除症例の登録事業は、1994 年以来 5 年毎に登録が行われている，平均年齢や高齢者·女性·小型肺癌· 腺癌・I 期肺癌などの比率は年代を追うごとに増加し, 一方周術期合併症, 術死, 在院死はともに漸減して

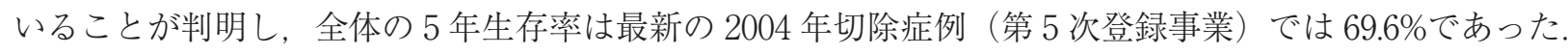

本年（2012 年）は, 第 6 次登録事業として内科初診症例を対象に前向き登録を開始しており，これまで に219施設の参加が得られている，本事業では，EGFR 遺伝子突然変異など近年の肺癌内科治療における重 要項目や具体的な治療内容を登録し，実地臨床の現状が明かになることが期待される。さらに 2016 年には 第 7 次登録事業として 2010 年の外科切除症例の登録を予定しており, 作業部会の立ち上げ準備をしている.

また 2016 年に TNM 分類の改訂が予定されているため、IASLC staging projectの統計解析センターに過 去の登録症例 47,306 例分のデー夕を提供した。これは現在の所世界で一番多数であり，日本の実地臨床が世 界標準作成事業に非常に貢献していると高く評価されている. 